\title{
Pengembangan Registri Psikotik Berbasis Rumah Sakit pada Rumah Sakit Jiwa Provinsi Jawa Barat
}

\author{
Elsi Rahmini ${ }^{1}$, Deni K. Sunjaya ${ }^{2}$, Guswan Wiwaha² \\ ${ }^{1}$ Dinas Kesehatan Kabupaten Rokan Hulu-Riau \\ ${ }^{2}$ Departemen Ilmu Kesehatan Masyarakat, Fakultas Kedokteran, Universitas Padjadjaran
}

\begin{abstract}
Abstrak
Registri psikotik dapat memberikan informasi tentang penyakit jiwa yang mudah diakses serta menjadi alat perencanaan perawatan dan penanganan pasien psikotik. Tujuan penelitian adalah mengidentifikasi potensi, menggali struktur registri dan membangun kerangka konsep registri psikotik di Rumah Sakit Jiwa Provinsi Jawa Barat. Penelitian menggunakan desain kualitatif dengan paradigma konstruktivisme dan pendekatan riset operasional. Metode pengumpulan data dengan wawancara mendalam, Focus Group Discussion dan observasi pada 17 responden. Analisis data melalui koding, kategorisasi, penyusunan tema dan interpretasi data. Potensi registri psikotik di Rumah Sakit Jiwa Provinsi Jawa Barat terdiri dari komponen input dan process yaitu: kualitas SDM, SOP, jaringan, pembiayaan, data klinik awal, sarana penunjang (input); perencanaan, pelaksanaan, dan evaluasi (process). Struktur registri berupa input yang terdiri dari kualitas SDM, SOP, software, jaringan, pembiayaan, serta data klinik awal. Kerangka konsep registri psikotik berupa perencanaan, pelaksanaan dan evaluasi. Ketiga proses tersebut memerlukan input berupa kualitas SDM, SOP, software, jaringan, pembiayaan, data klinik awal dan sarana penunjang, output berupa data demografi, data administrasi dan data klinik. Outcome registri psikotik berupa manajemen klinik dan riset data informasi. Kerangka konsep yang dibangun dapat menjadi dasar implementasi riset. Registri psikotik yang dibangun akan mendukung kebijakan pengelolaan gangguan jiwa di Provinsi Jawa Barat dan nasional.
\end{abstract}

Kata kunci : Pengembangan, Psikotik, Registri

\section{Developing a Hospital-Based Psychotic Registry at West Java Province Mental Hospital}

\begin{abstract}
Psychotic registry provides accessible information on mental diseases and serves as a device useful for planning the care and treatment of psychotic patients. The objectives of the research were to identify potentials, to explore registry structure, and to build a conceptual framework of psychotic registry at West Java Province Mental Hospital. The research used a qualitative design with a constructivism paradigm and an operational research approach. The data collection methods applied were in-depth interview, Focus Group Discussion (FGD), and observation of 17 respondents. Data analysis was done by coding, categorization, theme arrangement, and data interpretation. The potentials of psychotic registry at West Java Province Mental Hospital consisted of input and process components, namely: HR quality, SOP, network, finance, initial clinic data, and supporting facility (input); planning, implementation, and evaluation (process). The registry structure was in form of inputs consisting of HR quality, SOP, software, network, finance, and initial clinic data. The conceptual framework of the psychotic registry consisted of planning, implementation, and evaluation. The three processes needed some inputs informs of HR quality, SOP, software, network, finance, initial clinic data, and supporting facilities, and output in forms of demographic, administrative, and clinic data. The outcomes of psychotic registry were clinic management and information data research. The built conceptual framework can be used as a basis of research implementation. The built psychotic registry may support the policies of mental disorder management in West Java Province and at national level.
\end{abstract}

Keywords : Development, psychotic, registry

Korespondensi:

Elsi Rahmini, SKM

Dinas Kesehatan Kabupaten Rokan Hulu-Riau

Jl. Komplek Perkantoran Pemda Kab. Rokan Hulu, Kota Pasir Pengaraian

Mobile : 08974360026

Email : rahminielsi79@gmail.com 


\section{Pendahuluan}

Gangguan psikotik muncul sebagai gejala dari sejumlah gangguan mental, termasuk gangguan suasana hati (mood) dan gangguan kepribadian, skizofrenia, halusinasi, delusi, katatonia dan penyalahgunaan zat. ${ }^{1}$ Di negara-negara miskin dan berkembang sebanyak $76-85 \%$ penderita gangguan jiwa tidak menerima pelayanan, sementara di negara-negara maju $35-50 \%$ penderita gangguan jiwa mengalami hal yang sama. $^{2}$

Di Indonesia, data Riskesdas tahun 2013 sekitar 57.000 orang penderita gangguan jiwa atau $14,3 \%$ pernah atau sedang dipasung. Angka pemasungan di pedesaan sebesar $18,2 \%$, lebih tinggi jika dibandingkan dengan angka di perkotaan, yaitu sebesar $10,7 \% .^{3}$

Registrigangguan psikotikmerupakan hal yang sangat penting dalam sistem pelayanan kesehatan jiwa, karena dapat memberikan informasi penting tentang penyakit jiwa yang dengan mudah dapat diakses dan merupakan alat untuk perencanaan perawatan pasien gangguan psikotik serta upaya penanganannya. Disamping itu registri gangguan psikotik dapat pula digunakan sebagai sumber data untuk penelitian terkait. Registri adalah metode sistematis dari pencatatan berbagai parameter medis dan demografi dari populasi atau pasien tertentu yang diselenggarakan secara berkesinambungan. ${ }^{4}$

Mengingat belum tersedianya registri gangguan psikotik ini, maka akan dilakukan modifikasi pola-pola registri penyakit kronis yang sudah terbentuk seperti registri kanker, yang selanjutnya akan modifikasi untuk diterapkan dalam rencana pengembangan registri psikotik.

\section{Metode}

Penelitian ini dilaksanakan di Rumah Sakit Jiwa Provinsi Jawa Barat, dimulai pada bulan Mei hingga September 2016. Penelitian ini menggunakan desain kualitatif dengan paradigma kontruktivisme dan pendekatan riset operasional. Diperoleh 17 responden yang dipilih dengan teknik purposive sampling, yaitu 5 orang tenaga administrasi, 6 orang perawat, 1 orang dokter umum, 4 orang dokter spesialis dan 1 orang petugas farmasi dengan kriteria inklusi yaitu orang yang terlibat langsung dalam penatalaksanaan pasien gangguan jiwa yaitu dokter dan perawat, orang yang bertugas mendukung upaya kesehatan jiwa yaitu Direktur dan tenaga Administrasi, sedangkan kriteria ekslusi yaitu tidak berada ditempat selama waktu pengumpulan data dan tidak bersedia untuk menjadi informan.
Dilakukan indepth interview dan focus group discussion dengan menggunakan panduan wawancara dengan menggunakan pertanyaan terbuka. Selanjutnya dilakukan analisis menggunakan content analisis dengan proses transkripsi, koding, kategorisasi dan penyusunan tema serta interpretasi data dengan menerapkan trustworthiness.

Penelitian ini telah memperoleh surat kelaikan etik penelitian dari Komite Etik Penelitian Kedokteran Kesehatan Fakultas Kedokteran Universitas Padjadjaran Bandung dengan Nomor 311/UN6.C1.3.2/KEPK/PN/2016.

\section{Hasil}

Analisis data menghasilkan 108 lembar transkrip wawancara, 362 koding, 41 sub kategori, 18 kategori, 5 sub tema dan 3 tema dengan interpretasi data sebagai berikut:

Potensi Pengembangan Registri Psikotik Berbasis Rumah Sakit pada Rumah Sakit Jiwa Provinsi Jawa Barat. Penelitian ini dilakukan eksplorasi potensi pengembangan registri gangguan psikotik berbasis rumah sakit pada Rumah Sakit Jiwa Provinsi Jawa Barat. Penelitian ini menghasilkan 2 sub tema yakni input dan process. Komponen input yang diamati adalah komponen Kualitas SDM, SOP (Standard Operating Procedure), Software, Jaringan, Pembiayaan, Data Klinik dan Sarana penunjang di Rumah Sakit Jiwa Provinsi Jawa Barat. Penelitian ini menemukan adanya SDM administrasi terkait SIMRS masih merangkap jabatan lain, sehingga menimbulkan keterlambatan pengoperasian SIMRS.

Belum juga sih masih tetap ada aja diruangan yang salah mindahin, telat mindahin, itu kembali lagi kepegawainya itu yah yang dia belum rasa penting gitu yah terkait SIMRS ini dan ada yang masih merasa, itukan bagian administrasi bukannya bagian kita tapi kalo dikaitkan dengan tupoksi tadikan yang itu bukan tupoksi saya. (R11, 47)

Kinerja pegawai merupakan perilaku nyata yang ditampilkan setiap pegawai sebagai prestasi kerja sesuai dengan perannya dalam sebuah instansi. Peran dan tanggung jawab yang dibebankan kepada pegawai dapat menjadi dasar penilaian atas prestasi kerja yang ditunjukkan. Dalam konteks penelitian ini diperoleh suatu data informasi bahwa pegawai bagian SIMRS masih dirangkap tugasnya dengan pegawai atau petugas bagian lain seperti perawat. Kondisi ini mengakibatkan rasa tanggung jawab yang melekat di pundak petugas lain lebih rendah dibandingkan jika tugas tersebut dilakukan oleh seorang 


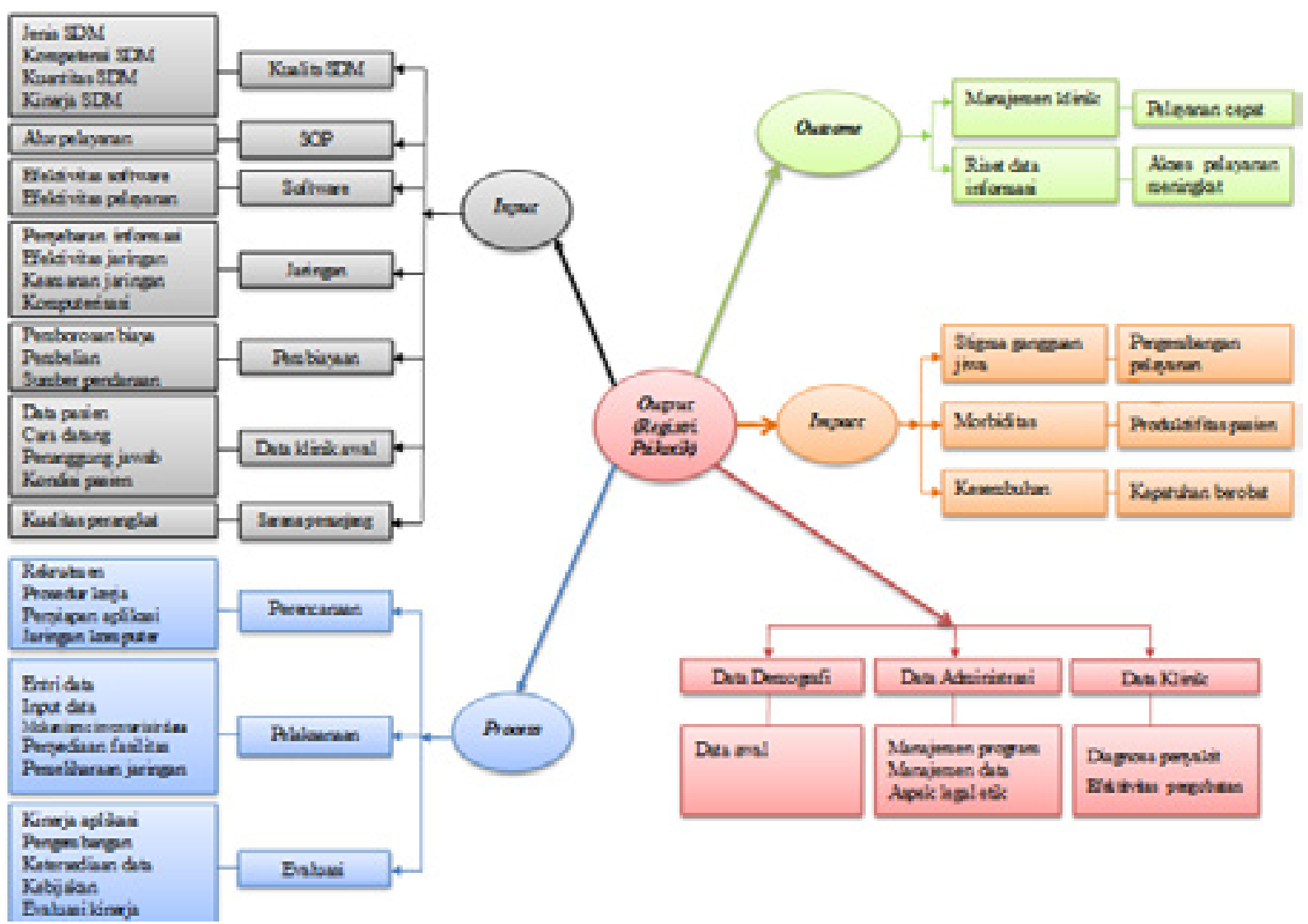

\section{Gambar 1 Peta Konsep Pengembangan Registri Psikotik Berbasis Rumah Sakit pada Rumah Sakit Jiwa Provinsi Jawa Barat}

pegawai administrasi. Potensi pengembangan registri gangguan psikotik berbasis rumah sakit pada Rumah Sakit Jiwa Provinsi Jawa Barat, berdasarkan hasil penelitian ini meliputi 2 tahapan jika dihubungkan dengan logic model, yaitu input dan process. Input meliputi kualitas SDM, SOP, Software, Jaringan, Pembiayaan, Data Klinik dan Sarana Penunjang. Process meliputi perencanaan, pelaksanaan dan evaluasi. Penelitian potensi tidak mencapai tahap output, outcome dan impact karena bertujuan untuk mendata kemampuan yang dimiliki RS dalam rencana proses pembuatan registri. Proses output, outcome dan impact tersebut akan dijelaskan dalam kerangka konsep yang akan menghasilkan keluaran berupa registri gangguan psikotik;

Struktur Registri Gangguan Psikotik Berbasis Rumah Sakit pada Rumah Sakit Jiwa Provinsi Jawa Barat. Untuk membangun registri psikotik perlu diketahui struktur yang ada di rumah sakit tersebut, sehingga pada tahap penelitian selanjutnya dilakukan eksplorasi mengenai struktur registri psikotik berbasis rumah sakit pada Rumah Sakit Jiwa Provinsi Jawa Barat. Pasien yang melakukan perawatan medis di
Rumah Sakit Jiwa Provinsi Jawa Barat umumnya menjadi tanggung jawab keluarganya. Walaupun demikian sebagai rumah sakit yang melayani perawatan medis kepada pasien gangguan jiwa tidak menutup kemungkian ada pasien yang diantarkan dan menjadi tanggung jawab Dinas Sosial.

Kadang ada yang datang sendiri, ada yang sama keluarganya $(R 2,71)$

Pasien jiwa yang mendapatkan pelayanan medis di Rumah Sakit Jiwa Provinsi Jawa Barat menjadi tanggung jawab keluarganya baik ditinjau dari pendataan diri maupun pembiayaan. Berdasarkan hasil obsevasi dan wawancara dengan informan diperoleh informasi bahwa pasien jiwa itu tidak selalu diantarkan oleh anggota keluarganya ke rumah sakit. Beberapa dari pasien diantarkan oleh petugas dari Dinas Sosial karena pasien ditemukan di jalan atau di tempat umum lainnya. Kepada pasien dengan jenis ini maka rumah sakit memperlakukan berbeda terkait pendataan identitas diri maupun perekaman medis yang diperlukan. Sedangkan tanggung jawab pembiayaan atas perawatan menjadi tanggung jawab Dinas Sosial terkait. 
Penelitian pada tahap struktur yang bertujuan untuk menggali harapan Rumah Sakit Jiwa dalam pembuatan registri gangguan psikotik menghasilkan kualitas SDM berupa jenis SDM, SOP, software berupa efektivitas software, jaringan berupa komputerisasi, pembiayaan berupa pemborosan biaya dan sumber pendanaan, serta data klinik berupa cara datang dan penanggung jawab. Keseluruhan sub tema yang disebutkan di atas termasuk dalam tahapan input jika prosesnya dikaitkan dengan teori logic model. Penelitian struktur tidak meliputi process, output, outcome dan impact karena registri yang diharapkan belum terwujud. Lain halnya dengan SIMRS yang saat ini telah digunakan sebagai sistem pencatatan seluruh pasien di Rumah Sakit Jiwa, SIMRS diharapkan dapat digunakan sebagai acuan untuk membangun struktur pada registri gangguan psikotik;

Kerangka Konsep dalam Pengembangan Registri Gangguan Psikotik Berbasis Rumah Sakit pada Rumah Sakit Jiwa Provinsi Jawa Barat. Salah satu upaya untuk meningkatkan layanan gangguan psikotik maka Rumah Sakit Jiwa Provinsi Jawa Barat menerapkan SIMRS yang direncanakan memuat registri gangguan psikotik sebagaimana dikemukan oleh responden melalui Focus Group Disscusion berikut ini:

Cuman maksudnya gitukan registri psikotik, inikan peneliti pendahuluan ini, berarti ini kualitatif, tadikan udah disampaiakan, bahwa saya ingin datanya itu untuk pengembangan pelayanan, ya kemudian untuk mengurangi stikma, memperkenalkan gangguan jiwa pada masyarakat sehingga masyarakat itu tidak negativ pada ganguan jiwa gitu aja sih, ...(FGD, 43)

Melalui penerapan registri gangguan psikotik maka diharapkan terjadi peningkatan atau pengembangan layanan yang kemudian dapat mengurangi stigma (pandangan yang membedakan) tentang ganguan jiwa. Disamping itu adanya registri gangguan psikotik diharapkan pula terjadinya pertukaran informasi terkait gangguan jiwa dengan masyarakat. Lalu pada bagian akhirnya stigma masyarakat terhadap penyandang gangguan jiwa menurun. Kalau semua hal itu dapat dicapai maka pasien gangguan jiwa dapat kembali ke masyarakat dan meneruskan hidupnya untuk beraktivitas seperti biasanya.

Pada gambar kerangka konseptual diatas menerangkan proses dan sumber daya dalam Pengembangan Registri gangguan Psikotik Berbasis Rumah Sakit pada Rumah Sakit Jiwa Provinsi Jawa Barat. Pembiayaan, SDM dan IT merupakan sumberdaya yang mutlak diperlukan dalam tahap awal pengembangan registri psikotik. Ketersediaan sumberdaya dilanjutkan dengan proses pelaksanaan berupa pelayanan pengambilan data pada pasien ganguan psikotik yang datang kerumah sakit terutama pasien baru,

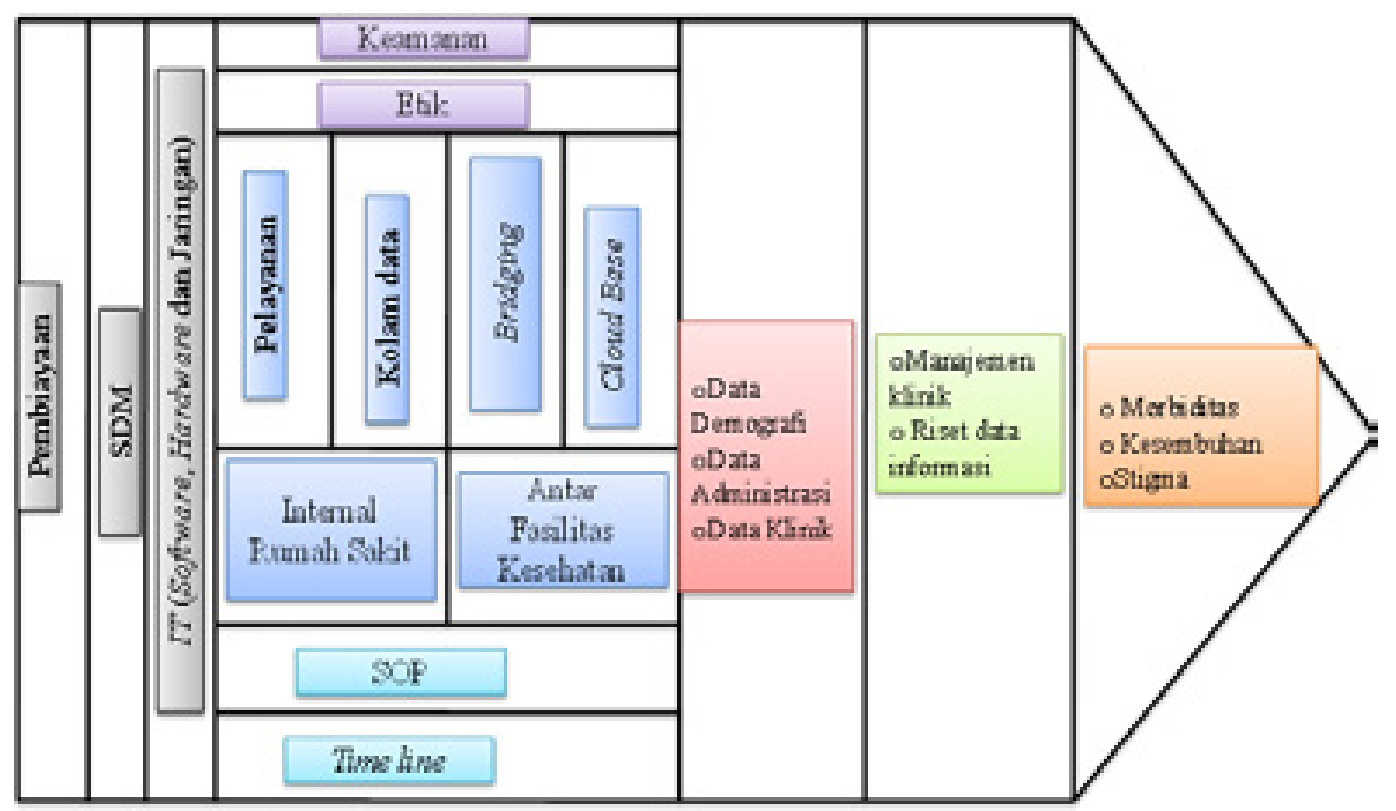

Gambar 2 Kerangka Konseptual Pengembangan Registri Psikotik Berbasis Rumah Sakit pada Rumah Sakit Jiwa Provinsi Jawa Barat 
sementara data pasien lama telah tercatat dalam SIMRS. Penggunaan finger print dan deteksi retina pasien dapat dipertimbangkan sebagai pembuka akses data mengingat pasien gangguan psikotik tidak bisa diwawancarai. Data pasein baru dan lama terkumpul dalam suatu sistem yang disebut kolam data. Data pasien lama yang ada dalam SIMRS akan disalin kedalam registri gangguan psikotik menggunakan bridging berupa sistem software yang menjembantani SIMRS dan registri gangguan psikotik. Data pasien gangguan psikotik yang telah terkumpul dari SIMRS dan registri gangguan psikotik tersimpan dalam cloud base yang sewaktu-waktu dapat diambil oleh yang mempunyai akses. Data tersebut dapat digunakan oleh internal rumah sakit yang bersangkutan ataupun antar fasilitas kesehatan terkait. Proses pengambilan, penyimpan dan pengeluaran data harus memenuhi kaidah keamanan dan etika kerahasiaan pasien. Keseluruhan proses yang telah diterangkan diatas dilandasi oleh SOP dan time line yang telah disiapkan sebelumnya.

Proses yang telah dilaksanakan akan menghasilkan data demografi, data administrasi dan data klinik yang bermanfaat untuk peningkatan manajemen klinik dan riset data informasi, untuk mencapai tujuan akhir berupa menurunnya morbiditas psikotik, meningkatkan kesembuhan dan menghilangkan stigma gangguan psikotik dimasyarakat.

\section{Pembahasan}

Peningkatan mutu sumber daya manusia kesehatan, dan kegiatan manajemen sumber daya manusia merupakan kunci utama suksesnya misi rumah sakit dalam meningkatkan derajat kesehatan bangsa. ${ }^{5}$

Semua pegawai yang bekerja di Rumah Sakit Jiwa Provinsi Jawa Barat tentunya memiliki kompetensi khusus sesuai dengan bidang kerjanya masing-masing. Jika ditinjau dari sumber daya manusia sistem juga belum dijalankan oleh petugas dengan keahlian khusus yang menangani hal ini. Input dan process data masih dilakukan oleh petugas kesehatan. Dalam kondisi darurat petugas kesehatan akan lebih mementingkan melakukan tindakan medis ke pasien sementara input data harus ditunda dulu pengerjaannya. Kompetensi adalah suatu kemampuan untuk melaksanakan atau melakukan suatu pekerjaan atau tugas yang dilandasi atas keterampilan dan pengetahuan serta didukung oleh sikap kerja yang dituntut oleh pekerjaan tersebut. Dengan demikian, kompetensi menunjukkan keterampilan atau pengetahuan yang dicirikan oleh profesionalisme dalam suatu bidang tertentu sebagai sesuatu yang terpenting, sebagai unggulan bidang tersebut. ${ }^{6}$

Adanya perencanaan yang baik akan membuat semua aktivitas yang dilakukan menjadi terarah dengan baik pula. Jika semua aktivitas yang dilakukan sudah dijalankan sebagai mana mestinya maka keberhasilan mencapai tujuan sudah ada di depan mata. Jadi sudah jelaslah bahwa keberhasilan sebuah organisasi membuat perencanaan yang baik merupakan suatu usaha untuk mencapai keberhasilan organisasi secara keseluruhan. Berdasarkan hal tersebut maka dapat dikatakan bahwa perencanaan mutlak harus ada dalam setiap organisasi. ${ }^{7}$

Salah satu fitur dasar komputer adalah kemampuannya untuk mempertukarkan data dengan perangkat lain. Kemampuan komunikasi ini memungkinkan operator untuk menggunakan keyboard dan layer display untuk mengolah teks dan grafik. ${ }^{8}$ Penyajian dan visualisasi data melalui internet memungkinkan untuk dibuat dalam bentuk interaktif dinamis dan menarik dengan efek animasi. Beberapa hal perlu diperhatikan dalam penyajian dan visualisasi data melalui internet, antara lain kapasitas bandwith dan kompatibilitas teknologi yang digunakan, agar data yang disajikan dapat diakses dan di interpretasi dengan baik di sisi pengguna. ${ }^{9}$

Pada saat ini data tidak harus dalam bentuk kumpulan huruf, dalam bentuk kata atau kalimat, tapi bisa juga dalam bentuk suara, gambar diam dan bergerak, baik dalam bentuk dua atau tiga dimensi. Data sekarang banyak berkembang dalam bentuk data virtual/ maya yang merupakan hasil rekayasa komputer. ${ }^{10}$ Manfaat data adalah sebagai satuan representasi yang dapat diingat, direkam, dan dapat diolah menjadi informasi. Karakteristiknya, data bukanlah fakta, namun representasi dari fakta. Kata sederhananya, data adalah catatan tentang fakta, atau data merupakan rekaman catatan tentang fakta. ${ }^{11}$

Sistem komputerisasi ini diharapkan lebih sederhana, mudah dan cepat sehingga kebutuhan data pasien segera dapat dipenuhi dalam waktu singkat. Sebagai mana yang ada dalam Peraturan Mentri Kesehatan Indonesia nomor 82 tahun 2013 tentang Sistem Informasi Manajemen Rumah Sakit yang menyatakan bahwa pembentukan sistem informasi manajemen rumah sakit dilakukan dalam rangka meningkatkan efisiensi dan efektivitas penyelenggaraan rumah sakit di Indonesia. ${ }^{12}$

Menyangkut registri gangguan psikotik yang akan dibuat, terdapat 2 alternatif usulan sistem terkait keberadaan SIMRS yang sudah digunakan sebagai sistem pencatatan di Rumah Sakit Jiwa Provinsi Jawa Barat saat ini. Pertama adalah registri psikotik dibuat dalam software terpisah 
dan dibuatkan jembatan atau penghubung sistem (interface) yang merupakan media penghubung antar subsistem, yang memungkinkan beberapa sumber data dapat mengalir dari satu subsistem ke subsistem lainnya. Untuk subsistem lainnya melalui sebuah media penghubung, serta untuk mengintegrasikan antar subsistem menjadi satu kesatuan. ${ }^{13}$ Sehingga data yang diperlukan dalam registri gangguan psikotik dapat diambil dari SIMRS. Kedua adalah registri gangguan psikotik terintegrasi dalam software SIMRS yang berarti juga membuka akses semua data yang ada di SIMRS, hal ini harus mendapat izin dari pihak rumah sakit tersebut. Untuk saat ini semua komputer yang tersambung ke LAN (local area network) sudah menggunakan SIMRS.

Komponen output yang diamati adalah komponen Data Demografi, Data Administrasi, dan Data Klinik di Rumah Sakit Jiwa Provinsi Jawa Barat sebagai berikut: ${ }^{14}$

Data demografis meliputi: Nama pasien, Alamat dan nomor telepon pasien, Tanggal lahir, Jenis kelamin dan suku, dan bila ada Nomor jaminan sosial (kesehatan); Data Administrasi: meliputi Tanggal dan waktu pendaftaran, Siapa yang memberikan dan memasukkan informasi, Sumber rujukan, sendiri atau rumah sakit lain, Cara datang, misalnya dengan ambulan atau jalan kaki, Pilihan kamar dan dokter yang merawat, Nomor rekening dan atau nomor rekam medis pasien.; Data klinik meliputi: Rincian hasil pemeriksaan pasien, Diagnosis, Nama dokter, alamat dan nomor telepon, Perintah dokter, Rencana perawatan dan pengobatan.

Penelitian sebelumnya pada registri kanker menyatakan bahwa Undang-Undang nomor 29 tahun 2004 tentang praktek kedokteran, pasal 46 menyebutkan setiap dokter dan dokter gigi dalam menjalankan praktek kedokteran wajib membuat rekam medis. Berdasarkan peraturan registri kanker tahun 1992 bahwa registri kanker berisi data yaitu ${ }^{15}$ Informasi demografi dari masingmasing penderita kanker, Informasi pekerjaan atau riwayat pekerjaan dari individu yang terkena kanker, Informasi administratif, termasuk tanggal diagnosis dan sumber informasi, Data patalogi dari karakteristik kanker, termasuk tempat, stadium kanker, kejadian dan tipe pengobatan.

Jika dibandingkan dengan data registri gangguan psikotik, terdapat kesamaan tapi bedanya hanya di data patologi. Didata registri gangguan psikotik yang ada data klinik karena data patologi di registri kanker digunakan untuk menentukan karakteristik kanker termasuk dimana kanker itu berada, sementara data klinik pada registri gangguan psikotik menyatakan tipe pengobatan serta terapi apa yang didapat dalam pengobatan.
Penerapan aplikasi registri gangguan psikotik diharapkan dapat meningkatkan teknik layanan yang dilakukan oleh petugas medis. Tindakan keperawatan yang tepat karena adanya dukungan data pasien terutama terkait rekam medis akan memudahkan pelaksanaan tindakan medis yang tepat dan cepat. Oleh karena itu keberadaan registri gangguan psikotik ditujukan untuk mempercepat proses tindakan atau asuhan keperawatan bagi pasien yang di rumah sakit.

Hasil penelitian diatas ditemukan konsepkonsep yang berdasarkan dari responden dapat berpengaruh dalam membangun kerangka registri gangguan psikotik di Rumah Sakit Provinsi Jawa Barat. Kerangka konsep yang telah dibangun dapat menjadi dasar implementasi riset. Registri gangguan psikotik yang dibangun akan mendukung kebijakan pengelolaan gangguan jiwa di Provinsi Jawa Barat.

\section{Daftar Pustaka}

1. Undang-Undang Republik Indonesia Nomor 18 Tahun 2014 Tentang Kesehatan Jiwa.

2. WHO. Mental Health: a State of WellBeing. In World Healht Organization Media Centre. Oktober 2015. (diunduh 1 November 2015). Tersedia dari: http://www.who.int/ mediacentre/ factsheets/ fs396/en/

3. Kementerian Kesehatan RI. Riset Kesehatan Dasar (Riskesdas) Tahun 2013. Jakarta: Balai Penelitian dan Pengembangan Kesehatan; 2013.

4. Prakash J, TS RamakrishnanTS, Das RC K. Srivastava, Mehta S, and Shashikumaret R. Central registry in psychiatry: A structured review. Ind Psychiatry J. 2014 Jan-Jun; 23(1): 10-14.

5. Aditama TY. ManajemenAdministrasi Rumah Sakit. Jakarta: Universitas Indonesia;2003.

6. Wibowo. Manajemen Kinerja. Jakarta: PT. Raja Grafindo Persada;2007.

7. Rusniati, Ahsanul H. Perencanaan Strategis dalam Perspektif Organisasi. Jurnal INTEKNA:2014. (diunduhpada25 Juli2017); Vol. 14, No. 2: 102-209. Tersedia dari: http:// download.portalgaruda.org/article.php?art icle $=352623 \& \mathrm{val}=8097 \&$ title $=$ PERENCA NAAN\%20STRATEGIS\%20DALAM\%20 PERSPEKTIF\%20ORGANISASI

8. Departemen Pendidikan Nasional. D3 TKJ (Teknik Komputer dan Jaringan). Modul 12: 2010 (diunduh pada 30 Juli 2017) Tersedia dari: https://adisupe.files.wordpress. com/2010/07/modul_12_-_input_output.pdf

9. Wibowo A Analisa $\overline{\text { Dan }}$ Perancangan Sistem Dashboard Management Sebagai 
Sarana Memvisualisasikan Informasi Data PT DHARMA POLIMENTAL, 2010(diunduh 08 Agustus 2017) Tersedia dari http://digilibesaunggulacid/public/ UEU-Undergraduate-5118-abstrak1_ari_ wibowopdf Abstrak.

10. Deni D, Kunkun NF. Sistem Informasi Manajemen. Bandung: PT. Remaja Rosdakarya; 2016.

11. Yonatan LP. Sistem Informasi Manajemen Agenda Pada Badan Pelayanan Perijinan Terpadu Kabupaten Karanganyar. BPPT Karanganyar. Journal Speed-Sentra Penelitian Engineering dan Edukasi; Vol 3 No 3 - 2011 (diunduh pada 26 Juli 2017); Trsedia dari: http://ijns.org/journal/index. php/speed/article/view/1261/1249.
12. Peraturan Menteri Kesehatan Republik Indonesia nomor 82 tahun 2013 tentang Sistem Informasi Manajemen Rumah Sakit. 2013.

13. Hakam F. Analisis, Perancangan dan Evaluasi Sistem Informasi kesehatan. Yogyakarta: Gosyen Publising; 2016.

14. Mahalul A. Sistem Informasi Admisi Pasien Rawat Inap untuk Membantu Pengambilan keputusan Klinis dan Administrasi di Badan Rumah Sakit Umum daerah (RSUD) DR.H. Soewondo Kabupaten Kendal; 2007.

15. Budi S C. Sistem Pencatatan Data Pasien Kanker di RSUP Dr. Sardjito. Jurnal Manajemen Informasi Kesehatan Indonesia. Universitas Gajah Mada (UGM): ISSN:2337585X, Vol.2, No.1, 2014. 